\title{
The Hourglass Effect: The Late
}

\section{Seventeenth Encyclopaedic Dictionary and the Dissemination of Knowledge}

O efeito da ampulheta: o dicionário enciclopédico do final do século XVII e a disseminação do conhecimento

\section{Geoffrey Clive Williams*}

williams@licorn-research.fr https://orcid.org/0000-0001-8790-7534

\author{
Ioana Galleron ${ }^{* *}$ \\ ioana.galleron@sorbonne-nouvelle.fr \\ https://orcid.org/0000-0003-0393-4485
}

\begin{abstract}
The publication of the Dictionnaire universel of Furetière in 1690 ushered in the age of the encyclopaedic dictionary. This was a relatively short-lived phenomenon of little more than a hundred years, but one which pathed the way to modern encyclopaedias. Furetière having died in 1688, his successor was Basnage de Beauval, a protestant exile based in the United Provinces of the Netherlands. It was Basnage who in the new 1701 edition transformed the dictionary by enlarging it considerably to a more genuine encyclopaedic coverage and calling on specialists to rewrite key sections, notably on the natural sciences. The simile of the hourglass is a means to show how the dictionary mediated knowledge from a vast array of sources and made the data available to contemporary and current day users. This paper demonstrates the hourglass effect through the lexicographical and learned sources that Basnage and his major compiler of scientific data, Regis of Amsterdam, brought into service. It looks at how Regis used numerous botanical sources in writing entries on Brazilian flora. Finally, we examine the influence of the work on the phenomenon of the universal dictionary and the development of the encyclopaedia.
\end{abstract}

Keywords: Historical Lexicography; Retrodigitisation; Encyclopaedic Dictionaries; Source Tracking; Botany.

\footnotetext{
* Université Grenoble Alpes \& Université Bretagne Sud, UMR 5316 Litt \& Arts - UGA, Grenoble, France.

** Université Sorbonne-Nouvelle Paris 3, UMR 8094 LATTICE - USN, Paris, France.
}

\section{LINHA DÁGUA}




\begin{abstract}
Resumo
A publicação do Dictionnaire universel de Furetière em 1690 marcou o início da era do dicionário enciclopédico. Este foi um fenómeno relativamente curto com pouco mais de cem anos, mas que abriu caminho para as enciclopédias modernas. Tendo Furetière falecido em 1688, seu sucessor foi Basnage de Beauval, um protestante exilado sediado nas Províncias Unidas da Holanda. Foi Basnage quem, na nova edição de 1701, transformou o dicionário, ampliando-o consideravelmente para uma cobertura enciclopédica mais genuina e chamando especialistas para reescrever secções-chave, principalmente sobre as ciências naturais. A analogia da ampulheta é uma maneira de mostrar como o dicionário mediou o conhecimento de uma vasta gama de fontes e disponibilizou os dados para utilizadores contemporâneos e atuais. Este artigo demonstra o efeito de ampulheta através de fontes lexicográficas e eruditas que Basnage e seu principal compilador de dados científicos, Regis de Amsterdão, colocaram em serviço. O artigo examina como Regis utilizou várias fontes botânicas para escrever entradas sobre a flora brasileira. Por fim, examina a influência da obra no fenómeno do dicionário universal e no desenvolvimento da enciclopédia.
\end{abstract}

Palavras-chave: Lexicografia histórica; Retrodigitalização; Dicionários enciclopédicos; Rastreio de origem; Botânica.

\title{
Introduction
}

The publication of the Dictionnaire universel of Furetière in 1690 ushered in the age of the encyclopaedic dictionary. This was a relatively short-lived phenomenon of little more than a hundred years, but one which pathed the way to modern encyclopaedias. Furetière having died in 1688, his successor was Basnage de Beauval, a protestant exile based in the United Provinces of the Netherlands. It is Basnage who, in the new 1701 edition, transformed the dictionary by enlarging it considerably to a more genuine encyclopaedic coverage and calling on specialists to rewrite key sections, notably on the natural sciences. The simile of the hourglass is a means to show how the dictionary mediated knowledge from a vast array of sources and made the data available to contemporary and current day users. This paper demonstrates the hourglass effect through the lexicographical and learned sources that Basnage and his major compiler of scientific data, Regis of Amsterdam, brought into service. More specifically, it looks at how Regis used numerous botanical sources in writing entries on Brazilian flora. Finally, it discusses the influence of the work on the phenomenon of the universal dictionary, and the development of encyclopaedia.

Dictionaries are often seen as the supreme reference and arbitrator of word meaning. The notion that a dictionary says what a word really means is fundamentally wrong. This is a frequent and unfortunate fallacy. The history of lexicographical endeavours, from glosses via catholicons to dictionaries, is one of increasing decontextualization, when meaning can only really be found in context. Lexicographical elegance (RUNDELL, 2010) is about concision, reducing language knowledge to a minimum. However, what that means is that rather than being a concentration of knowledge, dictionaries are essentially tools for disambiguation. They

\section{LINHA DÁGUA}


represent the knowledge of the lexicographer, or the analysis made by a lexicographer from a large amount of data, and nowadays this means electronic corpus. As (HANKS, 1986) has so nicely put it, a dictionary can at best demonstrate meaning potentials, not meanings. Dictionaries, as opposed to other works of reference, essentially deal with words rather than things. On the other hand, encyclopaedias do attempt to encapsulate knowledge, and provide means to dig further into a subject. They are essentially about things and have developed since their beginnings, in works as Chambers' Cyclopaedia and the great encyclopaedia of Diderot and d'Alembert, to become vast repositories of knowledge, typified nowadays by Wikipedia.

However, the difference between dictionaries and encyclopaedias has not always been so clear cut. In the late seventeenth century there arose a new type of dictionary, one that dealt with both words and things, and which endeavoured the be a reference work for knowledge. Its greatest exponent is probably the Dictionnaire Universel, henceforth DU, of Antoine Furetière (FURETIÈRE, 1690) and most particularly the 1701 edition under the direction of Henri Basnage de Beauval (FURETIÈRE, 1701). It is this work that is the direct ancestor of the modern encyclopaedia and it principal author, abbé Antoine Furetière (1619-1688) was, in the words of Rey (REY, 2006), a precursor of the age of enlightenment. Furetière had been unable to publish his work in France, and so through the good offices of the protestant exile Pierre Bayle, it was published in the United Provinces of the Netherlands.

In this paper, we shall describe the ongoing work on digitising the DU (WILLIAMS; GALLERON, 2016) and insight the management of some the data through what we call the hourglass effect. The hourglass effect attempts to illustrate how large amounts of data are compiled as input mediated through definitions that then act as a knowledge base for users. Input here takes the form of earlier dictionary sources and the array of other works consulted by the compilers. The range of texts that may be used in encyclopaedic entries is illustrated through the botanical hourglass seen in the context of descriptions of Brazilian trees. We then look at how idea of a universal dictionary was taken up and how the DU influenced, directly or indirectly, other works.

\section{Digitising the DU}

In carrying out the analyses in this paper, we make use of a fully digitised version in XML-TEI format. Whilst a first attempt at digitising the DU is described in (WIONET; TUTIN, 2001), this project worked on a 1702 edition, which seems in fact to be a two-volume pirate version printed in France, and simply copying the true three-volume 1701 version. Only the letter D was attempted, and the files were never made available. Thus, more recently in 2015 an independent project was started within the context of the Consortium Cahier ${ }^{1}$ of HumaNum, the French national scheme for the development of digital humanities. This initial project

1 Available at: https://cahier.hypotheses.org Last accessed: 03 mar. 2021.

\section{LINHA DÁGUA}


consisted in working from scratch on the letter $\mathrm{C}$ in XML-TEI as a means to explore the possibilities of in-depth mark-up and to prepare the ground for full digitalisation of the entire work. Full digitalisation became possible with French National funding for a consortium built from research teams in the universities of Grenoble-Alpes and Sorbonne-Nouvelle, in collaboration with Inria, the French national institute for applied computing ${ }^{2}$. The aim is to digitise all four major editions - 1690, 1701, 1708 and 1725/27 -, as well as the rival Trévoux dictionary of 1704, in fact a total plagiarism of the 1701 DU carried out by Jesuits in an attempt to undermine the protestant Dutch publishing industry.

The digitalisation process is a massive one, in that the work consists of over 3000 pages of text organised in two columns. This is far too much for human intervention, so the task of preparing a TEI version was carried out using GROBID-Dictionaries (KHEMAKHEM et al., 2017), by adapting this software to the needs and particularities of historical dictionaries. GROBID-Dictionaries requires an OCR in a dual layer PDF so as to have both the initial layout and the text. A high quality OCR is essential (KHEMAKHEM et al., 2019), so we had the volumes rescanned by the Bibliothèque Nationale de France in order to have a higher degree of resolution before undertaking an OCR with Transkribus ${ }^{3}$. Numerous problems had to be overcome, due to page layout and the use of characters that are no longer in current use, such as the s-long which OCR frequently interprets as an $f$. Nevertheless, a usable working edition was obtained that was suitable for parsing by GROBID-Dictionnaries, and for use in a concordancer with a full private version being uploaded to SketchEngine.

GROBID-Dictionnaries works by tackling each level of analysis separately. This entails training the machine learning system at each level. The tool has performed extremely well down to the level of sense and sub-sense so that we now have a perfectly usable full version. Nevertheless, correcting at sense level is an ongoing and time-consuming process, as this is where a less than perfect OCR and the idiosyncrasies of a late seventeenth century dictionary make machine mark-up difficult. Once the sense level is correct, a first stage of crowd-sourced correction will take place using the TACT system developed at the University Grenoble Alpes ${ }^{4}$.

In addition to structural mark-up with Grobid dictionaries, work is underway to apply a Named Entity Recognition system using BERT technology under the designation CamemBERT (ORTIZ SUAREZ et al., 2020). Apart from the standard targets of NER, the challenge is to specifically locate the persons and works cited in the text. This is complicated by the need to differentiate persons who are mentioned, such a Julius Caesar and Jesus Christ, from persons who are actually cited, and from the use of abbreviations used for persons or texts when citing sources. Basnage supplied a list of persons cited with the abbreviations in the front matter of his edition. Unfortunately, not only the abbreviations are not always respected, but

\footnotetext{
2 Available at: https://anr.fr/Projet-ANR-18-CE38-0003 Last accessed: 03 mar. 2021.

3 Available at : https://transkribus.eu/lite/ Last accessed: 03 mar. 2021.

4 Available at : https://tact.demarre-shs.fr/actu Last accessed: 03 mar. 2021.
}

\section{LINHA DÁGUA}


also numerous variants are to be found. In addition, a very large number of other authors and works are cited. It is hoped that NER system will ultimately help with automatic mark-up of citations, as this was done manually in the work on letter $\mathrm{C}$.

In the meanwhile, a prosopographical profile is being built and stored in the TEI header for persons cited. Some of these, with abbreviations that often require a fair degree of disambiguation, come from an index provided by Basnage. It is not known how he compiled this list as far more works are actually cited. To date, 240 authors have been found and linked to a profile. We are fortunate that a detailed study has already been made of the life of Basnage (GRAVELEAU, 2018), so we can use this as a starting point. Dr Graveleau is currently within the project, working building detailed profiles of each author and also listing their works and the availability of those works as digital editions. In this way, we hope to obtain a deeper insight into the sources and construction of the entries. We wish to know who and what influenced the dictionary as well as mapping the influence it has in turn on other lexicographers and encyclopaedists.

\section{The hourglass effect}

The simile of hourglass can be a useful one in describing dictionaries insofar as these are essentially tools for mediating linguistic and encyclopaedic information. A good dictionary is based on the compilation of vast amounts of knowledge that has to be passed through the filter of lexicographical elegance (RUNDELL, 2010), that is the use of carefully constructed concise entries, before being gradually dispersed and appropriated by users. Past dictionaries often tended to have a literary bias and have citations, if any, drawn from so-called best authors. This is why the Dictionnaire universel of Furetière is so revolutionary in that the work, particularly in its 1701 edition by Basnage de Beauval, drew upon the most appropriate authors. Rather than prestige, the citations seek to show both usage and knowledge from the best and most up-to date sources. It is essentially a precursor of the age of the encyclopaedia (ROYGARIBAL, 2006). As such, the dictionary supplied contemporary readers with much valuable information and offers us an interesting insight into arts and sciences of the $17^{\text {th }}$ century, all the more so as the sources cited give the possibility of creating a virtual library, a corpus in many ways, of the works and authors consulted.

The prefaces to the dictionary give interesting insights into the motivations and methods (WILLIAMS et al., 2020). In the preface to the 1690 edition, written by the French philosopher Pierre Bayle as Furetière had died in 1688, the encyclopaedic nature is underlined:

On ne sera plus reduit, comme le sont tant de gens, dans les matieres même les plus communes, à recourir au mot vague de chose, de piece, $\&$ à faire des postures de mains $\&$ de pieds, (manieres qui passent avec raison pour rustiques) afin d'exprimer la figure, la situation, \& l'étenduë de ce dont on parle. Cet Auteur apprend à tout le monde, non seulement la nature des choses par leur matiere, leurs

\section{LINHA DÁGUA}


usages, leurs especes, leurs figures, \& leurs autres proprietez, mais aussi les termes propres dont il se faut servir pour les décrire. ${ }^{5}$

(One will not be obliged any more to use the vague words of 'thing', 'piece', as most of people do, even when speaking about very common things, or to gesticulate with hands and feet (all manners that are rightly considered as rustic) so as to indicate the figure, the position or the size of what one is talking about. This author teaches everybody the nature of each thing, its materials, its usages, the different sorts it comes in, but also the appropriate terms for describing these.) (BAYLE, 1690, s. p.)

This explains the wealth of terms in the dictionary, but also some of the inaccuracies in that although he consulted many sources, the work was essentially that of Furetière. What is most significant with Basnage, is that he recognised his own lack of knowledge in key areas and so called upon experts, notably a certain Mr Regis of Amsterdam:

Je ne mets pourtant pas sur mon compte les articles d'Algèbre. Cette science m'est inconnue. Je ne m'approprie point non plus ce qui regarde la Medecine, l'Anatomie, la Pharmacie, la Chirurgie, \& la Botanique. Je n'ai point voulu me fier à moi-même là-dessus. Un habile Mr. Regis, Medecin à Amsterdam homme s'en est chargé (FURETIÈRE, 1701, s. p.) ${ }^{6}$

It is precisely this use of experts and expert sources that makes the dictionary so significant and makes the hourglass effect so visible. The DU has many facets so a diversity of hourglasses can be observed, here we deal with two: lexicographical sources and botanical information.

5 Please note that all citations are in the French of the period. The dictionary has no page numbers, in any of its editions, therefore only the main sections ("Préface", tome) are indicated with the quotations.

6 In English: "I do not declare as mine the entries about algebra. I do not know this science. I do not claim either anything pertaining to medicine, anatomy, pharmacy, surgery and botanical sciences. I did not want to trust myself on these matters. A knowledgeable man, Mr. Regis, medical practitioner in Amsterdam, took charge of these".

\section{LINHA DÁGUA}




\section{The lexicographical hourglass}

Fig. 1: $16^{\text {th }}$ century hourglass ${ }^{7}$

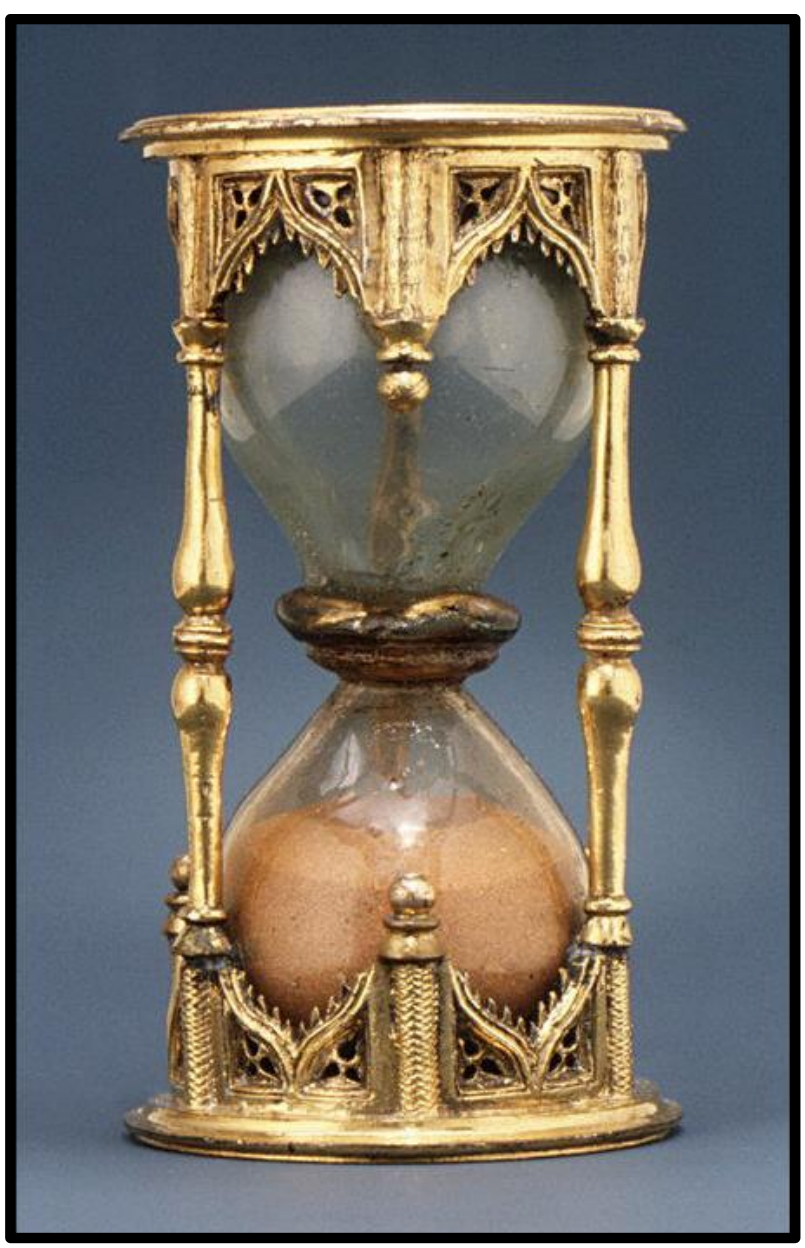

Furetière was at great pains to show that the dictionary was his own work and was in no way influenced by that of the Academy. The attempts by the Academy on what they saw as a rival dictionary, by preventing publication through use of their 40 years monopoly on producing a dictionary for the French language, led to open warfare and ultimately to Furetière's exclusion from the Academy. His bitterness was made quite clear in his Factums, the publications he wrote in his defence. Basnage did not have this problem. As an exiled Protestant, he was even keen to show his links with France and was therefore happy to compile his dictionary by making extensive use of published works, including that of the Academy and the Dictionary of arts and sciences of Corneille.

7 Metropolitan Museum of Art, $\mathrm{CC} 0$, via Wikimedia Commons. Available at: https://commons.wikimedia.org/wiki/File:Half-hour_sand_glass_MET_ES268.jpg Last accessed: 03 mar. 2021.

\section{LINHA DÁGUA}


Basnage cites other lexicographical works essentially when giving word histories and this is well illustrated in the entry for the noun Halte which cites the grammarian Vaugelas as well as the dictionaries of the Academy and Richelet.

HALTE. subst. f. Le h s'aspire. Terme de Guerre, [...] D'autres disent que c'est un mot Allemand, car on dit halten en même signification. Selon Vaugelas il faut écrire \& prononcer, Faire alte ; mais l'Academie est d'un autre sentiment, \& veut qu'on dise, Faire halte. Richelet admet l'un \& l'autre. Halte, se dit par extension, quand on s'arrête en faisant quelque chemin. [...] (FURETIÈRE, 1701, t. II) ${ }^{8}$

Claude Favre, seigneur de Vaugelas (1585-1650) was a founder member of the Académie Française and was the prime mover on work on the dictionary up to his death in 1650. As such, Furetière both knew and cited him.

The lexicographical hourglass thus opens with the sources used by Basnage, which are cited as references as above, or directly coped in so as increase coverage in specialised areas.

Fig. 2: The lexicographical sources

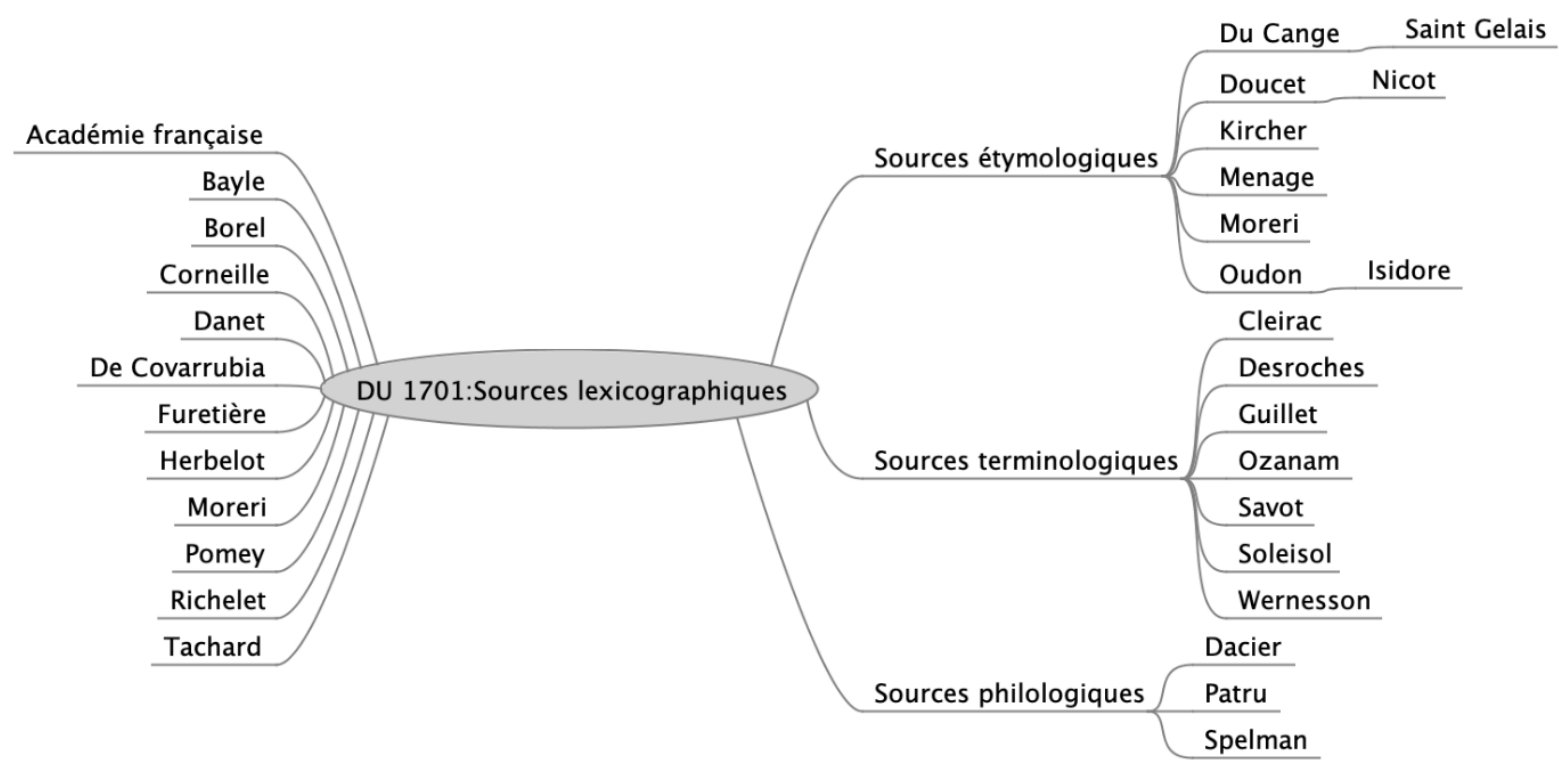

To the left, we have the lexicographical sources, some of which, such as Isidore, are indirectly quoted. Amongst the dictionaries, we find that of the Academy (ACADÉMIE FRANÇAISE, 1694) and that of Thomas Corneille (CORNEILLE, 1694), published hurriedly to counter that of Furetière. Whilst the Academy dictionary retained only 'polite' language, the accompanying Corneille contained terms from the arts and sciences so as to offset the encyclopaedic side of Furetière's DU. Corneille made heavy use for Richelet's 1680 dictionary, a work that got past the Academy's monopoly on dictionary writing by having been published in Geneva. A variety of other works were also consulted.

8 In English: "HALTE. Feminine noun. Aspired h. War term. [...] Some say this is a German word, since they use halten with the same meaning. Vaugelas says it has to be written and pronounced, Faire alte; but the Academy considers otherwise, and recommends, Faire halte. Richelet uses both. Halte means in general a stop one makes when travelling. [...]"

\section{LINHA DÁGUA}


To the right, we have his etymological sources with Menage and Du Cange supplying the majority of his word histories. We then have a series of terminological inputs including a dictionary of maritime terms (DESROCHES, 1697), a book specialised in architecture (SAVOT, 1624), another one on blacksmith craft (SOLLEYSEL, 1654), and so on. A third section consists of philological discussions, inspired by writers as the couple Anne (1645-1720) and André Dacier (1651-1722).

Whilst these sources were often cited in the dictionary text, definitions from Desroches were often simply copied in. (FENNIS, 1988) mapped the sources of maritime terminology in the DU, noting the heavy use of Desroches. This is currently being reanalysed using the digital versions so as to compare the $1690 \mathrm{DU}$, where some definitions are close to that of Desroches, to the 1701 edition where Basnage sometimes copied Furetière verbatim, sometimes copied in Desroches verbatim, and sometimes, as with the entry for AMURES, rewrote the entry both for the spelling and using Desroches to add details. The italics show what has been retained from Furetière.

Terme de Marine. Ce sont des trous pratiquez dans le platbord d'un vaisseau, \& dans la gorgere de l'éperon, pour y arrêter les cordages qui servent à bander les voiles. Les amures des voiles d'étay, sont de simples cordes. Les amures de la grande voile s'appellent dogues d'amures. L'amure d'une voile est son étoit, ou la manoeuvre qui sert à l'amurer. L'amure d'artimon, est un palanquin, ou quelquefois une corde simple. L'amure à basbord ou à tribord, c'est à droit ou à gauche. (FURETIÈRE, 1701, t. I) ${ }^{9}$.

Basnage was forced to work quickly and so the technique of copy-paste and comment was one he practiced often. In this case, he made use of an existing dictionary, but other sources are legion and the building of a virtual library for Basnage is a possibility, and one we are exploring.

In the prefaces, from that of Bayle onwards (WILLIAMS et al., 2020) mention is made of having made use of the finest authors. The Vocabulario of the Accademia della Crusca had done this, and so had Richelet, but the Académie Française had decided against, what is different in the usage of Furetière is that these are not simply to provide prestige to the entry, but are used to illustrate and bring in encyclopaedic information. Once CamemBERT is operational on the 1690 and 1701 editions we shall be able to compare sources, but it is quite clear that whilst Furetière relied heavily on his ex-circle in the Académie Française, Basnage was spreading his net far wider and tapping into the knowledge base of the protestant diaspora. This coupled with his European wide correspondence, his editorship of the journal Histoire des ouvrages savants and him being, according to Leibniz, a "secrétaire d'état' de la République des Lettres" (GRAVELEAU, 2018, p. 295), Basnage drew his information widely. To date, we

9 In English: Maritime term. These are holes made on the side of the ship, and to the front part, so as to place the ropes used to hoist the sails. The amures of shear sail are simple ropes. The amures of the great sail are called dogues d'amures. The amure of a sail is the manoeuvre that allows to hoist it. The amure of the mizzen is a pulley, or sometimes a simple rope. The larboard amure or starboard is right or left.

\section{LINHA DÁGUA}


found some 240 persons cited, and these represent the best of seventeenth century science, each with several highly relevant works to their name.

There is thus a vast knowledge base at work with Basnage either adding in information or calling upon specialists who entirely rewrote the entries from Furetière and added in others. As we shall see in the following section, the botanical hourglass, major rewriting was essentially the work of other contributors, and notably Regis.

\section{Input-Output: The botanical hourglass}

Whilst the move to encyclopaedic knowledge is a long-term influence, a more immediate output comes through the mediation of information through detailed entries. As mentioned earlier, Basnage did what Furetière had not succeeded in doing and produced a truly encyclopaedic dictionary by calling on expert input on scientific matters and on matters of language. We shall concentrate on the input from the medical practitioner Regis, and in particularly what he brought in through studies of flora and fauna.

A good point of departure for the exploration of entries concerning the natural sciences can be seen in the first part of the entry for a Brazilian animal, the Coati.

COATI. s. m. C'est un animal du Bresil diversement decrit par les Naturalistes, qui a un museau long d'un pied, rond comme un bâton, à peu-près comme la trompe d'un élephant, comme disent De Léri \& Marcgravius. Cependant il n'en a rien que la mobilité ; car il ressemble davantage à un grouin de pourceau. De Laet en fait deux especes : l'un qui a le poil roux par tout le corps, \& est appellé simplement coati ; \& est la femelle : l'autre qui n'a que le ventre \& la gorge de cette couleur, qu'on appelle coati mondi. On en a dissequé un de cette espece à l'Academie des Sciences, qui avoit six pouces depuis le bout du museau jusqu'à l'occiput, qui en avoit 16. jusqu'à la queuë, laquelle en avoit 13.de long.Il étoit haut de dix pouces. (FURETIÈRE, 1701, t. I)

The first issue here is why he added so many entries relating to Brazil. Brazil, Bresil in the dictionary, gets mentioned 98 times $^{10}$. This is considerable for a distant country and for flora and fauna that are generally designated by the local native population, Tupi, name, which can hardly be considered as in general or technical usage in France. The answer partially lies in the author cited and in Regis, the likely compiler of these entries.

As we have shown elsewhere (GRAVELEAU et al., 2021), there are two main reasons for the interest in Brazil, and both lie in the existence of a short-lived, $16^{\text {th }}$ century French colony on Brazilian territory called La France antarctique and the existence of a similar shortlived Dutch colony in the $17^{\text {th }}$ century. Both Basnage and Regis being French would certainly have known of the writings of the French priest Thevet and the protestant minister de Léry,

10 The information was obtained using SketchEngine on the partially cleaned OCR, so that the figures are not definitive. For term extraction, we use BaseX on the preliminary XML-TEI version so the same caveat applies.

\section{LINHA DÁGUA}


both of whom had visited the colony and described life there. The fact that there was a controversy over different appreciations of the local tribes with Thevet seeing them as savages and cannibals, and de Léry describing them as noble savages albeit mistaken in religion is, also a factor, especially with Basnage and Regis also being protestant. In the above example, de Léry's work Histoire d'un voyage fait en la terre du Brésil (LÉRY, 1578) is cited a source. The other source mentioned, Marcgravius, concerns the publication following a voyage of exploration to the Dutch colony undertaken by Willem Piso, who brought with him the naturalist Georg Margraf Marcgravius, who, in collaboration with Piso and De Laet, published a major work on the natural life of Brazil, Historia Naturalis Brasiliae... in qua non tantum plantae et animalia, sed et indigenarum morbi, ingenia et mores describuntur et iconibus supra quingentas illustrantur (MARCGRAVIUS; PISO, 1648). Our work suggests that the latter work, and numerous others formed the library of Regis, that it was he who chose the words to be entered and who compiled the entries (GRAVELEAU et al. 2021).

In the above-mentioned paper, we looked only at trees, which represent 31 entries. However, for these entries, we found some 12 different sources ${ }^{11}$, all of whom have clearly been consulted in building the descriptions. Amongst the sources we find the trio PisoMarcgravius-de Laet from which Regis translated sections from the Latin text. De Léry is another source, as was the French-speaking botanical school associated with, Gaspard Bauhin. An excellent example of compilation is the entry for JABANIPA. This is a fairly long entry for one of the larger trees found in Brazil. The entry itself has no source author mentioned so it is necessary to look at how the tree is described in source texts already located. Analysis shows that the use made of the juice of the fruit in body painting comes from (THEVET, 1558), but that the wording does not ${ }^{12}$. The actual description of the tree is drawn from (LAET, 1640) in French and from the Latin texts of (MARCGRAVIUS; PISO, 1648). In this way, what we have in the entry is condensed information from notable travel and naturalist sources so that the dictionary effectively mediates between learned sources and a knowledge base for the user.

Thus, whilst the lexicographical sources are situated at the top of the hourglass, the botanical hourglass shows input and output from sources to the immediate availability of data to a reader. Now we can now turn to how the knowledge spread.

11 See (Graveleau, Williams, et Villalva 2021) for details, but the following list reproduced from a note in the paper shows the twelves sources in chronological order: 1) (Thevet 1558), 2) (Léry 1578), 3) (Clusius 1611), 4) (Bauhin 1623), 5) (Parkinson 1640), 6) (Laet 1640), 7) (Marcgravius et Piso 1648) (the texts of Piso and Marcgravius were published together. Following the death of Marcgravius in 1644, Piso simply removed his name and claimed authorship of the whole. He did the same to de Laet who died in 1649), 8) (Rochefort 1658), 9) Jacques de Bondt ou Bontius, medici civitatis Batavia Nova... published in a work under the name of Piso in 1658, 10) (Tertre 1667) - 11) (Ray 1688) - 12) (La Loubère, de 1691). To these twelve, he also consulted the (Dictionnaire de l'academie francoise 1694) and the Dictionnaire des sciences et des arts of (Corneille 1694).

12 "Le suc de ce fruit est blanc d'abord, \& quand on s'en est frotté le corps, il noircit en peu de temps de telle sorte que les Sauvages s'en servent au lieu d'ancre, pour paroître plus terribles à leurs ennemis" (t. II). Translation: "the juice from this fruit is at first white, and when it is rubbed on the body, it blackens in a short while so that he savages use it instead of ink so as to appear more frightening to their enemies."

\section{LINHA DÁGUA}

Todo conteúdo da Linha D’Água está sob Licença Creative Commons CC -By 4.0. 


\section{Hourglass output: the influence of the Dictionnaire Universel}

This is a much more complex situation and one that is the subject of ongoing research. The various editions of the DU were involved in an interesting interplay with rival productions. Thus, the DU 1690 forced the Académie-Française into action so that they finally produced the dictionary that was to be their main task at their foundation 1635 some 60 years later in 1694 . This latter publication resulted in the Dutch publisher Leers inviting the protestant exile Henri Basnage de Beauval to produce a new version in 1701. This version was heavily revised and greatly increased in length and coverage. This was in turn plagiarised by the Jesuits of Trévoux in 1704, resulting in a marginally updated version from Basnage in 1708. It is at this point that the Trévoux dictionary began to break away from simply copying and moved towards the more encyclopaedic editions that followed.

Picking up on Basnage's comment cited above as to the use of specialised contributors, the Jesuits claimed to be doing likewise, and to be the first so to do, although this seems to have simply been rhetoric (LECA-TSIOMIS, 1999). Nevertheless, the 1721 Trévoux meant that Brutel de la Rivière, the successor to Basnage who died in 1710, had to take up again the revision that he had started earlier so that a new, and final version, of the DU was published in 1725/27. From this point on, the Trévoux Jesuits has a new enemy to fight, the humanists Diderot and d'Alembert. This then is one major use of the dictionary, albeit not cited as such.

In a similar way, reeditions of earlier dictionaries can also have been updated using, but not acknowledging, the 1701 DU. A case in point is the entry for 'Celestin' where he adds a story to illustrate the usage "voilà un plaisant Celestin" (this is a funny Celestine) an expression that is generally attributed to Richelet for its first attribution, but which is not to be found in the 1680 Richelet, but only in the 1724 version. (GRAVELEAU, forthcoming) Thus, the indirect influence is clearly present.

The 1690 dictionary was a great success and was part of the library of the great Danish lexicographer Matthias Moth (1649-1719) who was engaged on his Ordbog (EEGHOLMPEDERSEN, 2018). Moth apparently had no knowledge of the 1701 edition.

In terms of a direct heritage of the DU, we find the work of Rafael Bluteau (1638-1734) a French Jesuit born in London, but naturalized Portuguese. Bluteau's Vocabulario is the first major dictionary of Portuguese, and is also an encyclopaedic dictionary of the model of the DU. Bluteau has been inspired by the 1690 DU and it is this of which he made the most use when compiling his own dictionary (SILVESTRE, 2008). In his list of sources, in addition to DU 1690, Bluteau cites Richelet and the Academy and also a Dictionnaire Universel, 1709. Insofar as the second Basnage was published in 1708 , this must be either a mistake, or a pirate edition.

Silvestre demonstrates the reliance of Bluteau on Furetière through the example of the entry for DIAPHRAGME, in which the wording in the 1690 DU (s. p.) is: "Terme de Medecine. Membrane ou muscle nerveux qui separe la poitrine d'avec le bas ventre, \& qui est comme une espece de plancher qui est entre les parties vitales \& les naturelles." This corresponds closely to that of Bluteau:

\section{LINHA D'ÁGUA}


DIAFRAGMA. (Termo Anatomico.) Derivase do Grego Diaphratein, que val o mesmo, que dividir huma cousa da outra, como frontal, ou muro divisorio. O diafragma, he hum paniculo, ou membrana musculosa, que atravessando o peito, divide, \& separa os membros vitaes, a saber, o coraçaõ, \& os bofes, dos membros naturaes, a saber, o baço, \& intestinos. (FURETIÈRE, 1701, s. p.)

The entry for diaphragm found in the 1701 DU had been heavily revised, presumably by Regis, so it is quite clear that Bluteau had relied on the earlier edition. Insofar as Bluteau's work was the basis for future encyclopaedic dictionaries of Portuguese, we see an ongoing inheritance that predates the Basnage edition, and hence also the pirate Trévoux dictionary.

The move to the domination of the encyclopaedia is also interesting to follow. Harris' Lexicon technicum of 1708 (HARRIS, 1708) did draw on Furetière, and this in turn inspired Chambers. In his preface, Harris admitted having consulted Furetière, but claimed it had been of little use to him: “And therefore, this and Mr Furetière's Dictionary may be Books well done in their way, and are certainly very useful for those who would be acquainted with the French Tongue; yet I did not find much assistance from them, [...]" (HARRIS, 1708, s. p.)

He details other works consulted, and notably the Dictionnaire des arts et des sciences (CORNEILLE, 1694) which he attributes to the Académie-Française although it was in fact a companion volume to their dictionary of the French language, and one designed to offset the encyclopaedic aspect of Furetière's work. For Harris, Corneille's work listed far too many nonscientific words and was primarily a tool "to improve and propagate the French language, than to inform and instruct the Humane mind in general". He also quotes more specialised works as the Dictionnaire mathématique of (OZANAM, 1691). From his comments, it seems clear that it was the 1690 version of the DU that he was using and not that of Basnage, he was thus also unaware of the Trévoux.

Whilst Harris had relatively limited aims, as Chambers notes in his preface (CHAMBERS, 2020, s. p.) he sought universality and thus indirectly refers to the model that had been created by Furetière where he claims that he will create a "Cyclopaedia, or, An universal dictionary of arts and sciences: containing the definitions of the terms, and accounts of the things signify'd thereby, in the several arts, both liberal and mechanical, [...]”.

On the other hand, whilst Chambers also lists sources, he mentions the Trevoux and not the Furetière: "What the French Academists, the Jesuits de Trevoux, Daviler, Chomel, Savary, Chauvin, Harris, Wolsius, and many more have done, has been subservient to my Purposes." The Academists presumably means the Corneille dictionary. Bocast (CHAMBERS, 2020, p. 5) believes that Chambers primarily used the 1721 Trévoux, although many of his definitions were verbatim from the $1701 \mathrm{DU}$, mediated by the 1704 Trévoux plagiarism.

In the Catholic world, unsurprisingly, it is the Trévoux version that spread the most, and thus the influence is assigned to the 1704 dictionary. Insofar as the latter was a simple copy, when we find mention in the Diccionario Castellano con voces de ciencias y artes (1786-1788) and the Diccionario Italiano, e Portuguez (1773-1774) of Joaquim José da Costa e Sá what

\section{LINHA D'ÁGUA}


they are citing is the work of Basnage and his contributors ${ }^{13}$. This is a hidden hourglass effect, but an important one given the prevalence of the encyclopaedic dictionary in the $18^{\text {th }}$ and $19^{\text {th }}$ centuries.

The dominance of the encyclopaedic dictionary was obviously weakened by the rise of genuine encyclopaedias from that of Alembert and Diderot onwards. These more specialised works deal with ideas and things more than words, but the inheritance of the Dictionnaire Universel is clear from the Avertissement to the third volume (DIDEROT; D'ALEMBERT, 1751) where d'Alembert states in no uncertain terms that:

Le Dictionnaire de Trévoux en particulier doit moins reprocher qu'aucun autre les emprunts à l'Encyclopédie; car ce Dictionnaire n'étoit dans son origine \& n'est encore en grande partie, qu'une copie du Furetiere de Basnage, ainsi que ce dernier l'a fait voir \& s'en est plaint dans son histoire des ouvrages des Savans $(n)$.

(The Trévoux dictionary in particular should not reproach more than any other to be borrowings of the Encyclopaedia as this dictionary was from its beginnings, and is largely still, just a copy of the Furetière of Basnage, as the last-mentioned saw and complained in his Histoire des ouvrages des savans). (DIDEROT; D'ALEMBERT, 1751, p. 3: viij)

As is pointed out, the fact that the Dictionnaire de Trévoux is more known explains why later editions of the 'Furetière' are less known. The Jesuits had done the utmost to hide their intellectual theft, but when accused of having had recourse to the 1748 Trevoux in compiling the encyclopaedia (LECA-TSIOMIS, 1999), the compilers are keen to re-establish the truth in writing the entry for Buses (hydraulique) they note that:

Nous avons averti que le Dictionnaire de Trévoux est en grande partie copié du Furetiere de Basnage. Ainsi quand nous citerons dans la suite le Dictionnaire de Trévoux, c'est seulement parce que le nom de celui - ci est plus connu, \& sans prétendre faire tort à l'autre qui a été son modele. Plusieurs des articles de l'Encyclopédie qu'on a prétendu être imités ou copiés du Trévoux, sont eux mêmes imites ou copiés de Basnage [...]

(We have warned that the Trévoux dictionary is to a great extent copied from the Furetière of Basnage. Thus, when in the following we cite the Trévoux dictionary,

13 A workshop on "Lexicographical networks in the $17^{\text {th }}$ and $18^{\text {th }}$ centuries" was held in Paris on the $31^{\text {st }}$ January 2020. Speakers included Monica Lupetti (University of Pisa) on Il Diccionario Italiano, e Portuguez (17731774) di Joaquim José da Costa e and Elena Carpi, (Università di Pisa), Francisco M. Carriscondo Esquivel (uma - iemyrhd - anle), Anglicismes introduits par le français dans le Diccionario Castellano con voces de ciencias y artes (1786-1788). Joao Silvestre, (Kings College London) presented Blueau's work as Furetière as an omitted source in Portuguese lexicography Kira Kovalenko, \& Georgiy A. Molkov (Russian Academy of Sciences) described Russian Multilingual Dictionaries of the $18^{\text {th }}$ C.: Relations with French Lexicography, the influence of Furetière and Basnage in Russia. An unfinished encyclopaedia, and hence another rival to the Trévoux was presented by Linn Holmberg, (Stockholm University), The Maurists' unfinished dictionary. The lexicographical background to Diderot and Alembert was provided by Marie Leca-Tsiomis, (Université ParisOuest Nanterre), La genèse lexicographique de l'Encyclopédie. Alexander Bocast was unable to attend, but his two works on the influence on Chambers are cited above. A book is to be published with these papers.

\section{LINHA DÁGUA}

Todo conteúdo da Linha D’Água está sob Licença Creative Commons CC -By 4.0. 
it is only because the name of this one is more widely known and not to bring damage to that which was its model. Several entries of the Encyclopaedia have been claimed to have been imitated or copied from the Trévoux, which were themselves imitated or copied from Basnage [...]) (LECA-TSIOMIS, 1999, p 3: $\mathrm{xvj}$ )

\section{Conclusion}

Encyclopaedic dictionaries were a relatively short lived, but highly influential phenomenon. The period starts with the publication of Furetère's Dictionnaire universel (FURETIÈRE, 1690) with a much enlarged and revised edition by (FURETIÈRE, 1701) and gradually dies out in the early nineteenth century after the rise of domination of the encyclopaedia in the eighteenth century. From the mid-nineteenth century onwards, under the influence of the Worterbuch by the brothers Grimm, dictionaries turned to questions of philology and more concise definitions leaving the large knowledge bases to the encyclopaedia. Nevertheless, their influence was considerable and the simile of the hourglass illustrates how Basnage revolutionised the genre by calling upon specialist input that would mediate knowledge from a large number of learned sources and make it available in a condensed form to readers of their time. Also, the nature of the sources gives a deep insight into the state of the art in the sciences of the time.

\section{References}

ACADÉMIE-FRANÇAISE. Dictionnaire de l'Academie Françoise. Paris: J.-B. Coignard, 1694.

BAUHIN, G. Pinax theatri botanici Caspari Bauhini,... sive Index Theophrasti Dioscoridis Plinii et botanicorum qui a seculo scripserunt opera. Basel : L. Regis (Basileae Helvet), 1623.

BAYLE, P. Préface. In : FURETIÈRE, A. Dictionnaire Universel, contenant généralement tous les mots françois tant vieux que modernes et les termes des sciences et des arts. La Haye \& Rotterdam: Arnout \& Reynier Leers, 1690, s. p.

CHAMBERS, E. A Circle of Knowledge for Definition in Chamber's Cyclopaedia. Edited by Alexander BOCAST. Anacortes: Berkeley Bridge Press, 2020.

CORNEILlE, T. Dictionnaire des Arts et des Sciences. Paris: Veuve J.-B. Coignard et J.-B. Coignard, 1694.

DESROCHES, N. Dictionnaire des termes propres de la marine. Paris: Aimable Auroy, 1687.

DIDEROT, D.; D’ALEMBERT, J. (Eds.). Encyclopédie, ou Dictionnaire raisonné des sciences, des arts et des métiers. Tome premier. Paris: Briasson, David l'aîné, Le Breton, Durand, 1751.

EEGHOLM-PEDERSEN, S. Mothstudier: Kildegrundlaget for den første store danske ordbog. Denmark: Universitets-Jubilæets danske Samfund, 2018.

FENNIS, J. Les sources du vocabulaire maritime dans le Furetière de 1701. Travaux de linguistique et de philologie, n. XXVI, v. 1, p. 75-94, 1988.

\section{LINHA DÁGUA}


FURETIÈRE, A. Dictionnaire Universel, contenant généralement tous les mots françois tant vieux que modernes et les termes des sciences et des arts. La Haye \& Rotterdam: Arnout \& Reynier Leers, 1690.

FURETIÈRE, A. Dictionnaire Universel, contenant généralement tous les mots françois tant vieux que modernes et les termes des sciences et des arts. 2e edition, revue, corrigée et augmentee par M. Basnage de Beauval. La Haye \& Rotterdam: Arnout \& Reynier Leers, 1701.

GRAVELEAU, S. 'Les hérésies sont d'utiles ennemies'. Itinéraire d'Henri Basnage de Beauval (1656-1710), avocat de la République des Lettres et penseur de la tolérance civile. Doctoral dissertation, Faculté d'Histoire, Université d'Angers, Angers (France), 2018.

GRAVELEAU, S. La Normandie et les Normands face à l'étranger dans le Dictionnaire universel d'Henri Basnage de Beauval. Le regard d'un enfant du pays porté depuis l'exil. Annales de Normandie. Forthcoming.

GRAVELEAU, S.; WILLIAMS, G. C.; VILLALVA, A. Les arbres du Brésil dans deux dictionnaires historiques: le Dictionnaire universel de Basnage et le Vocabulario de Bluteau. TradTerm. Forthcoming.

GRAVELEAU, S.; STINCONE, C.; WILLIAMS, G.; GALLERON, I. Linking Authors and Works in the Dictionnaire Universel by Basnage de Beauval (1701). Linked Pasts 6, London, Institute of Classical Studies - Schoo of Advanced Study University of London, 2020. Available at: https://ics.sas.ac.uk/events/linked-pasts-6/poster-session Last accessed: 25 jul. 2021.

HANKS, P. Typicality and meaning potentials. In: ZüriLEX '86 Proceedings. Zurich: Francke Verlag, 1986, p. 37-47.

HARRIS, J. Lexicon technicum, or, An universal English dictionary of arts and sciences: explaining not only the terms of art, but the arts themselves. London: Printed for Dan. Brown, Tim. Goodwin, John Walthoe, Tho. Newborough, John Nicholson, Dan. Midwinter, and Francis Coggan, 1708.

KHEMAKHEM, M.; FOPPIANO, L.; ROMARY, L. Automatic Extraction of TEI Structures in Digitized Lexical Resources using Conditional Random Fields. eLex 2017 Proceedings, Leiden: U. of Leiden, 2017. Available at: https://hal.archives-ouvertes.fr/hal-01508868v1 Last accessed: 03 mar. 2021.

KHEMAKHEM, M.; GALLERON, I.; WILLIAMS, G. C.; ROMARY, L.; ORTIZ SUAREZ, P. J. How OCR Performance can Impact on the Automatic Extraction of Dictionary Content Structures. Proceedings of the $19^{\text {th }}$ annual Conference and Members' Meeting of the Text Encoding Initiative Consortium (TEI) -What is text, really? TEI and beyond, Graz: U. of Graz, 2019. Available at: https://hal.archives-ouvertes.fr/hal-02263276 Last accessed: 03 mar. 2021.

LA LOUBÈRE, S. de. Du Royaume de Siam. Paris: J.-B. Coignard, 1691.

LAET, J. de. L'Histoire du Nouveau Monde ou Description des Indes occidentales. Anvers: Bonaventure \& Abraham Elsevier, 1640.

LECA-TSIOMIS, M. Écrire l'Encyclopédie. Diderot: de l'usage des dictionnaires à la grammaire philosophique. Oxford: Voltaire Foundation, 1999.

LÉRY, J. de. Histoire d'un voyage fait en la terre du Brésil. La Rochelle: Antoine Chupin, 1578.

MARCGRAVIUS, G.; PISO, W. Historia Naturalis Brasiliae... in qua non tantum plantae et animalia, sed et indigenarum morbi, ingenia et mores describuntur et iconibus supra quingentas illustrantur. Amsterdam: Elsevier, 1648.

ORTIZ SUARES, P. J.; DUPONT, Y.; MULLER, B.; ROMARY, L.; SAGOT, B. Establishing a New State-of-the-Art for French Named Entity Recognition. Proceedings of LREC - 12th

\section{LINHA DÁGUA}


Language Resources and Evaluation Conference, Marseille, U. of Aix-Marseille, 2020. Available at : https://hal.inria.fr/hal-02617950 Last accessed: 03 mar. 2021.

OZANAM, J. Dictionaire Mathematique ou Idée generale des Mathematiques. Paris: Estienne Michalet, 1691.

PARKINSON, J. Theatrum Botanicum = the Theater of Plants: Or, An Herball of a Large Extent. London: Tho. Cotes, 1640.

REY, A. Antoine Furetière : Un précurseur des Lumières sous Louis XIV. Paris: Fayard, 2006. ROCHEFORT, Ch. De. Histoire naturelle et morale des Isles Antilles de l'Amerique. Rotterdam: A. Leers, 1658.

ROY-GARIBAL, M. Le Parnasse et le Palais. L'ouevre de Furetière et la génèse du premier dictionnaire encycloédique en language française (1649-1690). Paris: Honoré Champion, 2006.

RUNDELL, M. Defining elegance. In SCHRYVER, G.-M. de (Ed.) A Way with Words. Kampala, Uganda: Menha Publishers, 2010, p. 349-375.

SAVOT, L. L'Architecture françoise des bastimens particuliers. Paris: F. Clouzier, 1624.

SOLLEYSEL, J. de. Le Parfait mareschal qui enseigne à connoistre la beauté, la bonté et les deffauts des chevaux, la manière de les conserver dans les fatigues des voyages. Paris: G. Clousier, 1654.

SILVESTRE, J. P. Bluteau e as origens da lexicografia moderna. Lisboa: Imprensa Nacional - Casa da Moeda, 2008.

TERTRE, J.-B. du. Histoire generale des Antilles habitées par les François. Paris: Thomas Jolly, 1668.

THEVET, A. Les Singularitez de la France antarctique, autrement nommée Amérique, et de plusieurs terres et isles découvertes de nostre tems. Paris: Maurice de la Porte, 1558.

VORSTIUS, E. Caroli Clusii Atrebatis Curae Posteriores..., Leiden : in officina Plantiniana Raphelengii, 1611.

WILLIAMS, G. C.; GALLERON, I. Digitizing the second edition of Furetière's Dictionnaire Universel: challenges of representing complex historical dictionary data using the TEI. In: Proceedings of the XVII th EURALEX International Congress. Tbilissi: Ivane Javakhishvili Tbilisi University Press, 2016, p. 647-652.

WILLIAMS, G. C.; GALLERON, I.; STINCONE, C. Announcing the Dictionary: Front Matter in the Three Editions of Furetière's Dictionnaire universel. In: Proceedings of the $X I X^{\text {th }}$ EURALEX Congress. Alexandropoulis: Democritus University of Thrace, 2020, p. 393-402.

WIONNET, C.; TUTIN, A. Pour informatiser le Dictionnaire universel de Basnage (1702) et de Trévoux (1704) : Approche théorique et pratique. Paris: Honoré Champion, 2001.

Submitted: 05/17/2021

Accepted: 06/02/2021 